\title{
Leachate Pollution of Soil of Enugu
}

\author{
Okafor, C. C. And Onwuka, S. U. \\ Department of Environmental Management, Nnamdi Azikiwe Univeristy, Anambra State, Nigeria.
}

\begin{abstract}
Owing to the careless disposal of wastes in Enugu State, leachate rich in selected sampled heavy metals are generated which pollute the surrounding soil of the area. Consequently, atomic absorption spectrophotometer (AAS) was used to investigate the concentration of the pollutants (heavy metals) in the leachate and soil. Three (3) samples each of soil and leachates were collected in locations in the two study area (Coal Camp and Abakpa Nike) and analyzed for arsenic (As), chromium (Cr), lead (Pb), iron (Fe), zinc (zn), copper (Cu), magnesium (Mg), Cadmium (Cd) and mercury ( $\mathrm{Hg}$ ). All the metals were empirically higher than the recommended standards. The study tested if there was an interaction between the leachate and soil of the area and revealed that an interaction exist between the two. Thus, heavy metal contamination of the soil is as a result of the leachate. This is attributed to careless disposal of wastes in the area giving rise to leachate. Efficient management of wastes, remediation of the polluted soil was recommended, as it can give rise to groundwater pollution or bioaccumulate in the food grown in the soil and pose health risks.
\end{abstract}

Keywords: Heavy metal, leachate, soil, pollution, Enugu, Nigeria.

\section{Introduction}

Human and industrial activities result in the discharge of various pollutants to the environment threatening the health of the population and damaging the quality of the environment by rendering it unsuitable (Abowei and Sikoki, 2005). Evidence abounds in literature that substantiate the fact that environmental degradation that results from pollutants generation has been traced to anthropogenic sources in the quest for exploiting nature as a source of means of livelihood. Various reasons have been attributed to the increasing intensity of environmental degradation as a result of pollution in the developing countries, among which are the fluctuating demographic parameters with an estimated bludgeoning human population, along with its attendant increase in waste generation (Erakhrumen, 2007). Many developing and industrialized countries of the world indiscriminately site human activities that generate mobile pollutants. There is no doubt that both the urban and rural areas of such countries have been adversely affected by these resultant pollutants and contaminants, resulting in losses in human, material and financial resources. This is because volumes of the resultant pollutants are continuously produced yearly through many human activities, including industrial activities, agricultural practices, waste disposal systems etc. Consequently, various levels of wastes in different states, including solid, liquid and gaseous, are released into the environment at discrete intervals or on continuous basis. These pollutants and contaminants, which may have short or long half-lives in the environment, have continued to damage the environment of the industrialized countries, having defied many painstaking control programs (Egboka et al, 1989 and Fano et al, 1987).

In an effort to improve our way of living through increasing industrialization and human activities, we release some chemical, physical, biological substances into the ecosystem. These substances tend to accumulate in the ecosystem to certain concentrations that they distort ecological balance thus becoming harmful to life; this is called pollution. However, some of these substances often referred to as pollutants become harmful even at minute concentrations (Okafor, 2007).

Soil contamination is caused by the presence of xenobiotic (human-made) chemicals or other alteration in the natural soil environment. This type of contamination typically arises from the rupture of underground storage tanks, application of pesticides, percolation of contaminated surface water to subsurface strata, oil and fuel dumping, leaching of wastes from landfills or direct discharge of industrial wastes to the soil. The most common chemicals involved are petroleum hydrocarbons, solvents, pesticides, lead and other heavy metals. This occurrence of this phenomenon is correlated with the degree of industrialization and intensities of chemical usage (Eze, 2008). The sources of heavy metal pollutants are metal mining, metal smelting, metallurgical industries, and other metal-using industries, waste disposal, corrosions of metals in use, agriculture and forestry, forestry, fossil fuel combustion etc (Wikipedia, 2009).

The concern over soil contamination stems primarily from health risks, from direct contact with the contaminated soil, vapours from the contaminants, and from secondary contamination of water supplies within and underlying the soil. Mapping of contaminated soil sites and the resulting cleanup are time consuming and expensive tasks, requiring extensive amounts of geology, hydrology, chemistry and computer modeling skills (USEPA, 2002). Contaminated soil directly affects human health through direct contact with soil or via 
inhalation of soil contaminants which have vaporized; potentially greater threats are posed by the infiltration of soil contamination into groundwater aquifers used for human consumption, sometimes in areas apparently far removed from any apparent source of above ground contamination (Wikipedia, 2011). Agriculture in these areas faces major problems due to heavy metal transfer into crops and subsequently into the food chain (Wikipedia, 2009). Health consequences from exposure to soil contamination vary greatly depending on pollutant type, pathway of attack and vulnerability of the exposed population. Chronic exposure to chromium, lead and other metals, petroleum, solvents, and many pesticide and herbicide formulations can be carcinogenic, can cause congenital disorders, or can cause other chronic health conditions. Industrial or man-made concentrations of naturally-occurring substances, such as nitrate and ammonia associated with livestock manure from agricultural operations, have also been identified as health hazards in soil and groundwater (USEPA, 2002)

\section{Study Problem}

As a result of poor provision of improper waste disposal systems or ignorance and carelessness on the part of the residents and bludgeoning population, wastes are carelessly littered and scattered on the environment.

A casual look at most urban centres in Nigeria, and indeed in Enugu State (Coal Camp and Abakpa Nike) reveals unplanned and unorganized uses of various locations for various purposes like solid waste dumping, effluents disposal, siting of wide scale toilet facilities, disposal of chemical wastes from human activities and wrong and frequent application of artificial fertilizers. These are done without regards to the degradation of the soil of the area. Coal Camp is an industrial area in Enugu State, with abundance of autorepair and servicing outlets and their associated businesses. Metallic materials like engine blocks, pistons, rings, rim; plastic products like fan belts and other numerous associated automobile parts, motorcycles, tricycles, refrigerators and air conditioners abound. Thinners paints, and sprays which are made of lead, chromium, cadmium e.t.c and used or spent fuel and oil are carelessly discarded and dumped on the soil and ground. Similarly, Abakpa Nike is the largest town in Enugu State with its attendant population and waste generation. Wastes are disposed carelessly in open dump and left to accumulate and pose serious threat to the environment. These include household wastes, medical wastes and others. These products are left on the open space; rain continuously falls on them, resulting to rusting and corrosion. The resultant particles are washed by flowing rainwater giving rise to pollutants (leachate) movement in the environment. These materials are rich in heavy metals e.g. paint which is made of lead, a carcinogen and mutagen as well.

The aim of this paper is to study the pollution of the leachate pollution of soil of Enugu with a view of making recommendation for effective management of the environment. To pursue this aim, the following objectives were pursued:

- to establish the concentration of the selected heavy metals in the leachate and soil sample

- to establish if there is an interaction between the leachate and soil of the area.

\section{Study Area}

This study is carried out in Enugu State. Coal Camp is found in Enugu South Local Government Area of Enugu State in the Eastern part of Nigeria. It lies within Latitude $6^{0} 30 \mathrm{~N}$ and Longitude $37^{0} 20 \mathrm{E}$.it is bordered on the North by Ogbete, to the west by Garki, to the East by Uwani and to the south by Awkunanaw. Abakpa Nike is found in Enugu East Local Government Area. It lies within latitude $6^{0} 32 \mathrm{~N}$ and longitude $7^{0} 32 \mathrm{E}$ and is bordered on the North by Trans-Ekulu, to the west by New Haven, to the East by Iji Nike and to the south by Emene (www.enugustate.gov.ng. accessed 23.11.2012). 


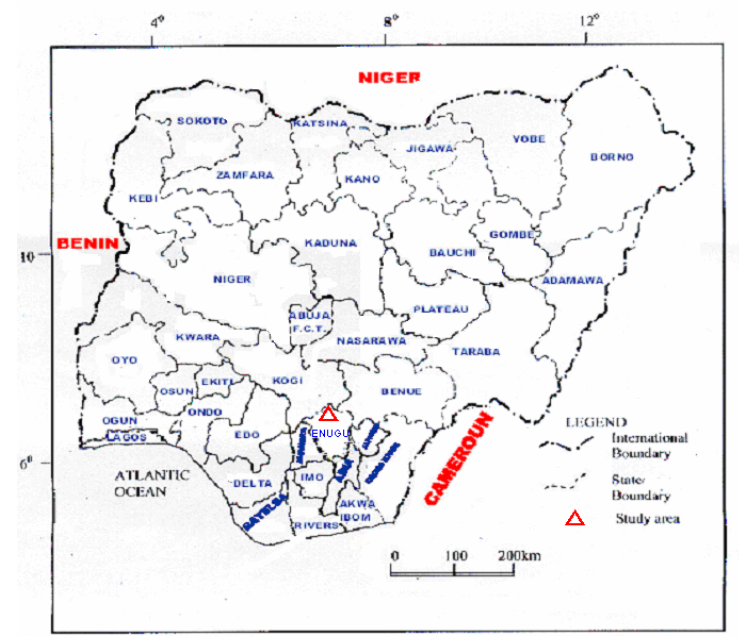

Fig. 1: Map of Nigeria showing Enugu State

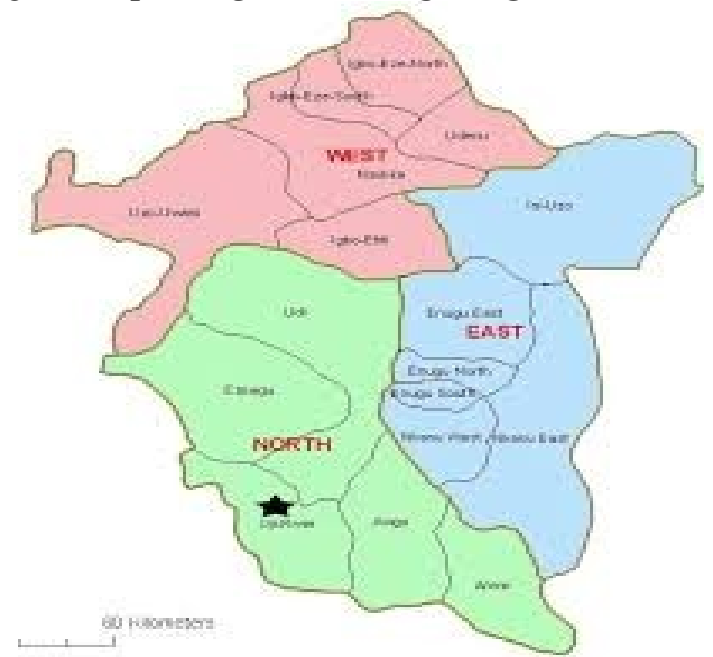

Fig 2: Map of Enugu State showing its LGAs

Two climatic seasons exist in the study area, namely rainy season (March - October) and dry season (November - March). The dry season is characterized by heavy down pours; it is also accompanied by thunderstorms, heavy flooding, soil leaching, extensive sheet out wash, ground infiltration and percolation. The annual rainfall of the area is over $2000 \mathrm{~mm}$. the study area lies within the rain-forest belt of Nigeria. In the south, the area is bounded by mangrove swamp forest, and in the north, by savannah grassland (Egboka and Okpoko, 1984)

Enugu is underlain by sedimentary formations of varying types and ages. Typical examples are Mamu Formation and Ajali Sandstone. Consequently, most of the formations, being mainly sandstone are good aquifers of high economic viability (Onwuka et al,2012). The Mamu Formation, previously known as Lower Coal Measures (Reymont, 1965), consists of fine-medium grained, white to grey sandstones, shaly sandstones, sandy shales, grey mudstones, shales and coal seams. The thickness is about $450 \mathrm{~m}$ and it conformably underlies the Ajali Sandstone. The Ajali Sandstone consists of thick friable, poorly sorted sandstones, typically white in colour but sometimes iron stained. The thickness averages $300 \mathrm{~m}$ and is often overlain by considerably thickness of red earth, which consists of red, earth sands, formed by the weathering and ferruginization of the sandstones (www.enugustate.gov.ng// geology accessed 28.09.2012). These formations trends generally North to South and various prominent landforms and related feature have been carved out of them (enugustate.gov.ng//coal camp accessed 28.09.2012)

\section{Theoretical Framework of the Study}

This work is built on the concept of the hydrogeopollution cycle. This is of great importance in understanding and explaining contaminants/pollutants movement through the environment. It incorporates hydrologic and geologic cycle into the transport and movement of pollutants through the ecosystem. Below is Fig 3 showing the hydrogeopollution cycle. 


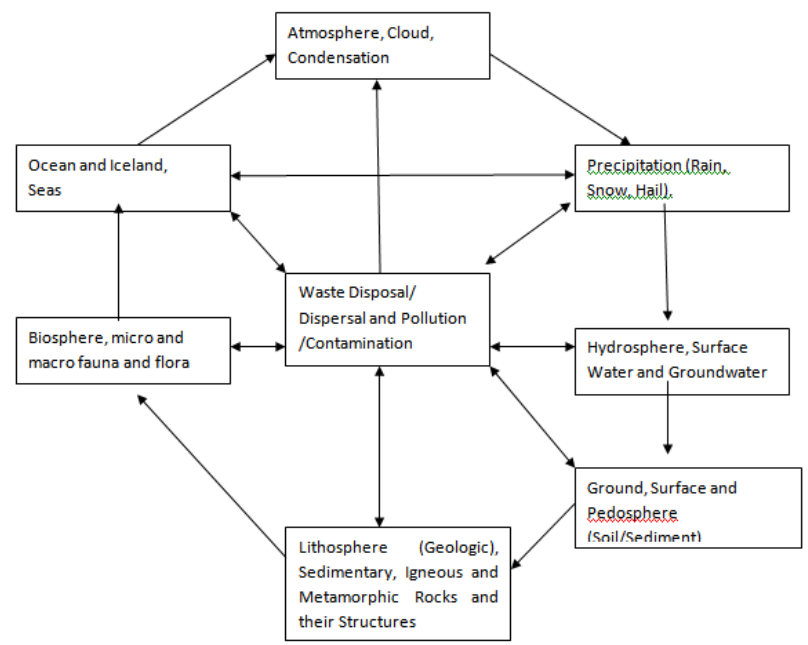

Fig.3 : The Hydrogeopollution Cycle (after Egboka et al, 1989).

Costain (1995), in his study of hydrogeopolluton cycle, stated that it involves the physical and chemical properties that influence pollutant transport; factors that influence the persistence of chemicals in the environment, partitioning of chemicals in the media of air, water and soil; biological and public and health risks from environmental contaminants. Krieger (1997) in his study ascertained that contaminants from pollution sources reach groundwater and soil through a combination of the actions of hydrologic and geologic cycle.

Ecosystem is a diverse biological continuity together with its natural environment. The components of the ecosystem - soil, water and air are linked in a continuum that allows for the transport and cycling of pollutants. This continuum is linked by physicochemical and biological interfaces for contaminant movement viz: gas-liquid interface (atmosphere and water); liquid-soil interface (water and soil); liquid - liquid interface (streams, rivers, lakes, oceans etc); soil - air interface and biological interface. The hydrologic cycle is composed of pathways, the various processes (condensation, evaporation, precipitation etc) by which water is cycled around. The cycle is in a state of equilibrium, as the total amount of water is constant. According to Nnodu and Ilo (2000), the hydrologic cycle is the endless circulation of water between the ocean, atmosphere and land, which is driven by sun's energy. Some of the evaporated water is returned as precipitation, part of which is rapidly evaporated back into the atmosphere. Some drain into lakes and rivers to commence a journey back to the sea. Some infiltrate into the soil and later percolates to become groundwater. In these processes, pollutants and contaminants introduced are cyclically transported through the hydrologic cycle.

Sources of pollution are either point source or distributed (diffused). Point sources of contamination are geographically defined; can be mapped; and are discernible in size, shape and location. Distributed sources are usually widespread throughout a large area with difficult boundaries to define. From the foregoing, therefore it is quite clear that the proper understanding of the migration of pollutants/contaminants will stem from the understanding of the hydrogeopollution cycle, part of which is the lithosphere.

\section{Materials And Methods}

Experimental design was adopted in this study. Due to the nature of the study, a judgmental/purposive sampling technique was chosen in selecting sites with which the laboratory analyses were run. This is because according to Babie (1973:106) purposive sampling is the most suitable in a study of this type. Three (3) soil samples were collected around the waste disposal site each in Coal Camp and Abakpa Nike into a clean and unused polyethene bag in order to avoid contamination, while also three (3) leachate samples each in both locations was taken directly from the dumpsite, to ascertain the concentration of heavy metal contamination on the surrounding soil. To enable the determination of the selected heavy metals in the selected soil sample using Atomic Absorption Spectrophotometer (AAS), the soil samples were sorted out. This was to remove any inorganic matter. It was then grounded to fine powdered form using an agate mortar and pestle leaving particle sizes in the nanometers range. Thus, increasing the surface area of the test sample. Samples were then sent to Ibeto Union Recycling Plant, Nnewi for FOR digestion and analysis.

Friedman Test was used to test if there was an interaction between the leachate and soil of the study areas. 
III. Result And Discussion Of Findings

Table 1: The distribution of heavy metal of the soil and leachate sample in Coal Camp

\begin{tabular}{|c|c|c|c|c|c|c|c|c|}
\hline & \multicolumn{4}{|l|}{ SS } & \multicolumn{4}{|l|}{$\mathbf{L L}$} \\
\hline Parameters & 1 & 2 & 3 & $\begin{array}{l}\text { Max. } \\
\text { acceptable } \\
\text { conc. In soil } \\
\text { (WHO) }\end{array}$ & 1 & 2 & 3 & $\begin{array}{l}\text { Max. Conc. In } \\
\text { drinking Water } \\
\text { (WHO) }\end{array}$ \\
\hline Arsenic & 1.45 & 1.30 & 1.02 & 0.025 & 1.2 & 2.18 & 1.05 & 0.01 \\
\hline Chromium & 1.1 & 0.99 & 1.0 & 0.25 & 0.92 & 0.48 & 1.00 & 0.05 \\
\hline Lead & 1.7 & 1.54 & 1.4 & 0.42 & 2.6 & 1.4 & 2.01 & 0.01 \\
\hline Zinc & 4.2 & 3.88 & 3.5 & 7.5 & 4.80 & 2.82 & 3.16 & 5 \\
\hline Copper & 2.4 & 2.2 & 1.8 & 0.1 & 1.283 & 3.00 & 2.145 & 1 \\
\hline Magnesium & 7.8 & 7.23 & 8.1 & NS & 18.56 & 13.11 & 22.09 & 50 \\
\hline Cadmium & 1.13 & 0.98 & 0.86 & 0.085 & 1.05 & 0.25 & 0.9 & 0.003 \\
\hline Mercury & 0.6 & 1.0 & 0.9 & 0001 & 0.29 & 0.90 & 0.7 & 0.001 \\
\hline
\end{tabular}

Source: Author's Field Work (2012).

*SS - soil sample . LL - Leachate sample.

Table 1 shows that the arsenic value all above WHO maximum acceptable standard in soil in all the stations with SS1, SS2 and SS3 having a concentrations of $1.45 \mathrm{mg} / \mathrm{g}, 1.30 \mathrm{mg} / \mathrm{g}$ and $1.02 \mathrm{mg} / \mathrm{g}$ respectively. Similarly, the readings0 in Stations 1,2 and 3 for chromium $(1.1 \mathrm{mg} / \mathrm{g}, 0.99 \mathrm{mg} / \mathrm{g}, 1.0 \mathrm{mg} / \mathrm{g})$, lead $(1.7 \mathrm{mg} / \mathrm{g}$, $1.54 \mathrm{mg} / \mathrm{g}, \quad 1.4 \mathrm{mg} / \mathrm{g})$, copper $(2.4 \mathrm{mg} / \mathrm{g}, 2.2 \mathrm{mg} / \mathrm{g}, 1.8 \mathrm{mg} / \mathrm{g})$ cadmium $(1.13 \mathrm{mg} / \mathrm{g}, 0.98 \mathrm{mg} / \mathrm{g}, \quad 0.86 \mathrm{mg} / \mathrm{g})$ and mercury $(0.6 \mathrm{mg} / \mathrm{g}, 1.0 \mathrm{mg} / \mathrm{g}, 0.9 \mathrm{mg} / \mathrm{g})$ were all above acceptable threshold . However, the concentrations in the three stations for iron $(10.02 \mathrm{mg} / \mathrm{g}, 9.5 \mathrm{mg} / \mathrm{g}, 11.08 \mathrm{mg} / \mathrm{g})$, zinc $(4.2 \mathrm{mg} / \mathrm{g}, 3.88 \mathrm{mg} / \mathrm{g}, 3.5 \mathrm{mg} / \mathrm{g})$ were all below WHO standards.

In the leachate sample, all the metals excluding zinc recorded concentrations greater than the standards with Arsenic $(1.2 \mathrm{mg} / 1,2.18 \mathrm{mg} / 1,1.05 \mathrm{mg} / \mathrm{l})$, chromium $(0.92 \mathrm{mg} / 1,0.48 \mathrm{mg} / 1,1.00 \mathrm{mg} / \mathrm{l})$, lead $(2.6 \mathrm{mg} / 1,1.4 \mathrm{mg} / \mathrm{l}$, $2.01 \mathrm{mg} / \mathrm{l})$, iron $(4.20 \mathrm{mg} / 1,2.9 \mathrm{mg} / 1,3.55 \mathrm{mg} / 1)$, copper $(1.283 \mathrm{mg} / 1,3.00 \mathrm{mg} / 1,2.145 \mathrm{mg} / 1)$, cadmium $(1.05 \mathrm{mg} / 1$, $0.25 \mathrm{mg} / 1,0.9 \mathrm{mg} / \mathrm{l})$ and mercury $(0.29 \mathrm{mg} / 1,0.90 \mathrm{mg} / 1,0.7 \mathrm{mg} / \mathrm{l})$. The concentrations of zinc were $(4.80 \mathrm{mg} / \mathrm{l}$, $2.82 \mathrm{mg} / 1,3.16 \mathrm{mg} / \mathrm{l})$.

Table 2: The distribution of heavy metal of the soil and Leachate in Abakpa Nike

\begin{tabular}{|l|l|l|l|l|l|l|l|l|}
\hline & SS & \multicolumn{9}{|l|}{ LL } & \multicolumn{3}{l|}{ Max. Conc. In } \\
& $\mathbf{1}$ & $\mathbf{2}$ & $\mathbf{3}$ & $\begin{array}{l}\text { Max. acceptable } \\
\text { conc. In soil } \\
\text { Parameters }\end{array}$ & $\mathbf{1}$ & $\mathbf{2}$ & $\mathbf{3}$ (WHO) \\
\hline Arsenic & 0.8 & 0.4 & 0.7 & 0.025 & 0.287 & 0.01 & 0.05 & 0.01 \\
\hline Chromium & 0.73 & 0.59 & 0.489 & 0.25 & 0.36 & 0.85 & 0.04 & 0.05 \\
\hline Lead & 1.02 & 1.1 & 1.08 & 0.42 & 0.9 & 1.2 & 1.1 & 0.01 \\
\hline Iron & 6.185 & 9.05 & 7.21 & NS & 1.8 & 2.4 & 1.24 & 0.3 \\
\hline Zinc & 3.39 & 2.1 & 2.6 & 7.5 & 1.21 & 3.4 & 2.1 & 5 \\
\hline Copper & 0.87 & 0.41 & 0.435 & 0.1 & 0.606 & 1.2 & 1.8 & 1 \\
\hline Magnesium & 4.83 & 6.2 & 6.0 & NS & 14.4 & 8.96 & 11.89 & 50 \\
\hline Cadmium & 0.36 & 0.40 & 0.105 & 0.085 & 0.17 & 0.092 & 0.19 & 0.003 \\
\hline Mercury & 0.8 & 0.07 & 0.2 & 0.001 & 0.002 & 0.01 & 0.01 & 0.001 \\
\hline
\end{tabular}

Source: Author's Field Work (2012).

LL - Leachate sample. SS - soil sample

Table 2 shows the arsenic value all above WHO maximum acceptable standard in soil in all the stations with SS1, SS2 and SS3 having a concentrations of $0.8 \mathrm{mg} / \mathrm{g}, 0.4 \mathrm{mg} / \mathrm{g}$ and $0.7 \mathrm{mg} / \mathrm{g}$ respectively. Similarly, the readings in Stations 1, 2 and 3 for chromium $(0.73 \mathrm{mg} / \mathrm{g}, 0.59 \mathrm{mg} / \mathrm{g}, 0.489 \mathrm{mg} / \mathrm{g})$, lead $(1.02 \mathrm{mg} / \mathrm{g}, 1.1 \mathrm{mg} / \mathrm{g}$, $1.08 \mathrm{mg} / \mathrm{g}), \quad$ copper $(0.87 \mathrm{mg} / \mathrm{g}, \quad 0.41 \mathrm{mg} / \mathrm{g}, \quad 0.435 \mathrm{mg} / \mathrm{g}) \quad$ cadmium $(0.36 \mathrm{mg} / \mathrm{g}, \quad 0.40 \mathrm{mg} / \mathrm{g}, \quad 0.105 \mathrm{mg} / \mathrm{g})$ and mercury $(0.6 \mathrm{mg} / \mathrm{g}, 1.0 \mathrm{mg} / \mathrm{g}, 0.9 \mathrm{mg} / \mathrm{g})$ were all above acceptable threshold. However, the concentrations in the three stations for iron $(6.185 \mathrm{mg} / \mathrm{g}, 9.05 \mathrm{mg} / \mathrm{g}, 7.21 \mathrm{mg} / \mathrm{g})$, zinc $(3.39 \mathrm{mg} / \mathrm{g}, 2.1 \mathrm{mg} / \mathrm{g}, 2.6 \mathrm{mg} / \mathrm{g})$ were all below WHO standards.

In the leachate sample, all the metals excluding zinc recorded concentrations greater than the standards with Arsenic $(0.287 \mathrm{mg} / 1,0.01 \mathrm{mg} / 1,0.05 \mathrm{mg} / \mathrm{l})$, chromium $(0.36 \mathrm{mg} / 1,0.85 \mathrm{mg} / 1,0.04 \mathrm{mg} / \mathrm{l})$, lead $(0.9 \mathrm{mg} / \mathrm{l}$, $1.2 \mathrm{mg} / 1,1.1 \mathrm{mg} / \mathrm{l})$, iron $(1.8 \mathrm{mg} / 1,2.4 \mathrm{mg} / 1,1.24 \mathrm{mg} / \mathrm{l})$, copper $(0.606 \mathrm{mg} / 1,1.2 \mathrm{mg} / 1,1.8 \mathrm{mg} / \mathrm{l})$, cadmium $(0.17 \mathrm{mg} / \mathrm{l}$, $0.092 \mathrm{mg} / 1,0.19 \mathrm{mg} / \mathrm{l})$ and mercury $(0.002 \mathrm{mg} / 1,0.01 \mathrm{mg} / 1,0.01 \mathrm{mg} / \mathrm{l})$. the concentrations of zinc were $(1.21 \mathrm{mg} / 1$, $3.4 \mathrm{mg} / 1,2.1 \mathrm{mg} / \mathrm{l})$. 


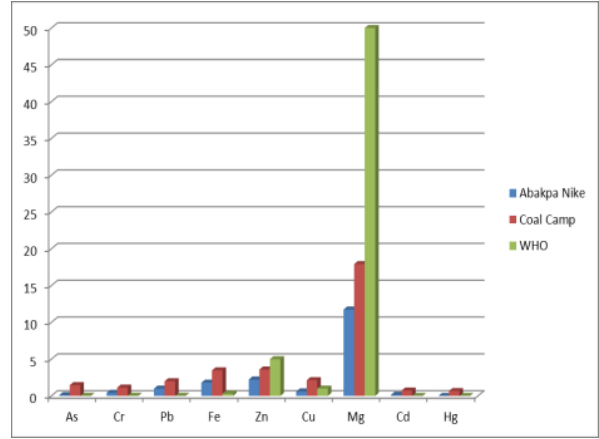

Fig. 3: Mean concentration of the heavy metals in the leachate of Abakpa Nike and Coal Camp

Fig. 3 shows that excluding zinc and magnesium, all the heavy metals were far above WHO Standard in the leachate sample in both areas. However, Coal Camp shows consistent more concentration than that of Abakpa Nike in all the metals.

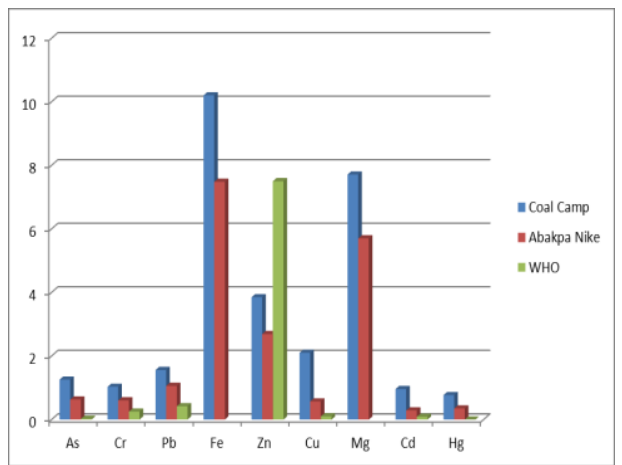

Fig.4: Mean Heavy metal properties of Soil Sample of Coal Camp, Abakpa Nike and WHO Standard for Quality Soil.

Fig. 4 shows that in locations areas, arsenic, chromium, lead, copper, cadmium and mercury were above WHO maximum concentration in soil. Where as they are below the standard for zinc.

\section{Discussion of Findings}

From Table 1, in Coal Camp, it shows that the arsenic values were all above WHO maximum acceptable standard in soil in all the stations with SS1, SS2 and SS3 having a concentrations of $1.45 \mathrm{mg} / \mathrm{g}$, $1.30 \mathrm{mg} / \mathrm{g}$ and $1.02 \mathrm{mg} / \mathrm{g}$ respectively. Similarly, the readings0 in Stations 1,2 and 3 for chromium $(1.1 \mathrm{mg} / \mathrm{g}$, $0.99 \mathrm{mg} / \mathrm{g}, \quad 1.0 \mathrm{mg} / \mathrm{g}), \quad$ lead $(1.7 \mathrm{mg} / \mathrm{g}, \quad 1.54 \mathrm{mg} / \mathrm{g}, \quad 1.4 \mathrm{mg} / \mathrm{g}), \quad \operatorname{copper}(2.4 \mathrm{mg} / \mathrm{g}, \quad 2.2 \mathrm{mg} / \mathrm{g}, \quad 1.8 \mathrm{mg} / \mathrm{g})$ cadmium $(1.13 \mathrm{mg} / \mathrm{g}, 0.98 \mathrm{mg} / \mathrm{g}, 0.86 \mathrm{mg} / \mathrm{g})$ and mercury $(0.6 \mathrm{mg} / \mathrm{g}, 1.0 \mathrm{mg} / \mathrm{g}, 0.9 \mathrm{mg} / \mathrm{g})$ were all above acceptable threshold. However, the concentrations in the three stations for iron $(10.02 \mathrm{mg} / \mathrm{g}, 9.5 \mathrm{mg} / \mathrm{g}, 11.08 \mathrm{mg} / \mathrm{g})$, zinc $(4.2 \mathrm{mg} / \mathrm{g}, 3.88 \mathrm{mg} / \mathrm{g}, 3.5 \mathrm{mg} / \mathrm{g})$ were all below WHO standards. Similarly, in Abakpa Nike, Table 2, it shows showed that the arsenic values all above WHO maximum acceptable standard in soil in all the stations with SS1, SS2 and SS3 having a concentrations of $0.8 \mathrm{mg} / \mathrm{g}, 0.4 \mathrm{mg} / \mathrm{g}$ and $0.7 \mathrm{mg} / \mathrm{g}$ respectively. Similarly, the readings in Stations 1, 2 and 3 for chromium $(0.73 \mathrm{mg} / \mathrm{g}, 0.59 \mathrm{mg} / \mathrm{g}, 0.489 \mathrm{mg} / \mathrm{g})$, lead $(1.02 \mathrm{mg} / \mathrm{g}, 1.1 \mathrm{mg} / \mathrm{g}, 1.08 \mathrm{mg} / \mathrm{g})$, copper $(0.87 \mathrm{mg} / \mathrm{g}, 0.41 \mathrm{mg} / \mathrm{g}, 0.435 \mathrm{mg} / \mathrm{g})$ cadmium $(0.36 \mathrm{mg} / \mathrm{g}, 0.40 \mathrm{mg} / \mathrm{g}, 0.105 \mathrm{mg} / \mathrm{g})$ and $\mathrm{mercury}(0.6 \mathrm{mg} / \mathrm{g}$, $1.0 \mathrm{mg} / \mathrm{g}, 0.9 \mathrm{mg} / \mathrm{g}$ ) were all above acceptable threshold. However, the concentrations in the three stations for iron $(6.185 \mathrm{mg} / \mathrm{g}, 9.05 \mathrm{mg} / \mathrm{g}, 7.21 \mathrm{mg} / \mathrm{g})$, zinc $(3.39 \mathrm{mg} / \mathrm{g}, 2.1 \mathrm{mg} / \mathrm{g}, 2.6 \mathrm{mg} / \mathrm{g})$ were all below WHO standards. There is non-uniform distribution of the heavy metals in both locations. These results implies the contamination / pollution of the soil and poses a threat to living organisms as it can bioaccumulate in plants. From Fig 4.6, the mean distribution of the metals in order of concentrations was as follows in Coal Camp: $\mathrm{Fe}>\mathrm{Mg}>\mathrm{Zn}>\mathrm{Cu}>\mathrm{Pb}>\mathrm{As}>\mathrm{Cr}>\mathrm{Cd}>\mathrm{Hg}$. In Abakpa Nike, it was $\mathrm{Fe}>\mathrm{Mg}>\mathrm{Zn}>\mathrm{Pb}>\mathrm{As}>\mathrm{Cr}>\mathrm{Cu}>\mathrm{Hg}>\mathrm{Cd}$. The mean concentration of the metals when compared with standards, showed that all the metals found in the soil of the study area exceeded the W.H.O Standard except zinc. Heavy metal distribution in Coal Camp were consistently higher empirically than that of Abakpa Nike.

Interaction was established between leachate and soil in both locations as shown by the P-value of 0.02 and 0.014 for Coal Camp and Abakpa Nike, respectively, which is significant at $0.05(\mathrm{P}>0.05)$. These revealed that all the metals are from the same source which may be coming from the dumpsite and metallic wastes from the auto-mechanic shops which are carelessly littered on the ground and thus, makes it anthropogenic in origin. 
This implies that the wastes from the mechanic shops and dumpsites littered around give rise to leachates which drips and pollute the immediate soil around the sites.

\section{Comparison between the Soil of Both Locations (Coal Camp and Abakpa Nike)}

Comparing the soil of Coal Camp to that of Abakpa Nike, From Tables 1 and 2, only zinc was below the permissible standard in both locations. However, $\mathrm{As}, \mathrm{Cr}, \mathrm{Fe}, \mathrm{Zn}, \mathrm{Mg}, \mathrm{Cd}$ and $\mathrm{Hg}$ mercury showed significant difference from that of Coal Camp. This implies that the heavy metal contamination of the soil in Coal Camp is higher than that of Abakpa Nike. This is attributable to the leachate pollution of the soil as deduced from the interaction between them as shown by p-value 0.02 and 0.014 respectively for Coal Camp and Abakpa Nike, which is significant at 0.05 . The higher contamination of the soil of Coal Camp as a result of leachate pollution is traceable to the metallic waste sites. This agrees with the work of Okafor (2012). This contamination of the soil of both study area poses a significant threat as it can bioaccumulate in plants grown in the area and biomagnify in humans who consumes its product. This has been documented. It can also be transported through surface run offs into nearby surface waters leading to its pollution. The metals are transported as either dissolved species in water or as an integral part of suspended sediments, They may be stored in stream bed sediments or seep into the underground sources, particularly wells; and the extent of contamination will depend on the nearness of the well to the waste site as reported by Garbarino et al (1995); Peplow (1999).

\section{Conclusion}

1. There are effects of Leachate on the chemical contamination of the soil of the study area. These arises from improperly disposed waste within and around the environment given rise to its contamination. Statistical analysis showed a relationship between the pollutant source (leachate) and the soil of the area. These pollutants pollute the soil of the area and are traceable to waste disposal and the auto-repair shops (anthropogenic) around the area.

2. In Coal Camp, $\mathrm{As}, \mathrm{Cr}, \mathrm{Pb}, \mathrm{Cu}, \mathrm{Cd}$ and $\mathrm{Hg}$ were significantly above W.H.O strandard for quality soil; whereas only $\mathrm{As}, \mathrm{Cr}, \mathrm{Pb}$ and $\mathrm{Cu}$ were significantly higher in the soil of Abakpa Nike.

\section{Recommendation}

Private and industries (mechanic shops) should manage their waste by devising a more efficient process that would minimize the amount of waste generated. However, this could be achieved by process of recycling. Environmental agencies should ensure adequate monitoring of these industries by carrying out routine inspections frequently.

In line with the routine inspection in No.5, Environmental Impact assessment (EIA) should be carried out by relevant environmental agencies from time to time so as to ascertain the level of environmental stress in the giving vicinity.

The remediation of the area should be carried out to avoid further circulation of these pollutants to the groundwater. Further research should be carried out on environmental studies. Research Institutes and Government Agencies should sponsor relevant research projects by providing research grants.

\section{References}

[1]. Abowei, J.F.N. and F.D. Sikoki, 2005. Water Pollution Management and Control, Double Trust Publications Company, Port Harcourt, ISBN: 978303802016, pp: 236.

[2]. Babie. E.R. (1973) Survey Research Methods, Belmont Wadsworth Publishing Company,USA.

[3]. Erakhrumen, A. A. (2012). Phytoremediation: an environmentally sound technology for pollution, prevention, control and remediation in developing countries. Education Research \& Review Vol 2(7):pp151 - 156.

[4]. Eze, L.C. (2008). Environmental Safety. Transparent Earth Nig. Ltd. Publication Port Harcourt. Rivers State..

[5]. Garbarino JR, Hayes H, Roth D, Antweider R, Brinton TI, Taylor H (1995). Contaminants in the Mississippi River, U. S. Geological Survey Circular 1133, Virginia, U.S.A. www.pubs.usgs.gov/circ/circ1133).

[6]. Okafor F.O. (2007). Heavy Metal Concentration of Three selected Fish Samples from the River Niger. An unpublished B.Sc thesis submitted to the Department of Pure and Industrial Chemistry, Nnamdi Azikiwe University Awka.

[7]. Onwuka, S.U., Okoye, C.O. and Onwuemesi, F.E. (2012). Mathematical Models for Predicting Pollutants Movement through Porous Rocks. Advances in Applied Research Vol 3(5): 3150 - 3159.

[8]. Soil and Environment: Heavy Metals on the Environment and their Health Effects. Tuesday, July 21, 2009 (www.wikipedia.com)

[9]. United States Environmental Protection Agency USEPA.(2002) Risk Assessment Guidance for Superfund, Human Health Evaluation Manual, Office of Emergency and Remedial Response, U.S. Environmental Protection Agency, Washington D.C. 20450 